\section{DIGITAL COMMONS \\ @ UNIVERSITY OF SOUTH FLORIDA}

\section{Revista Surco Sur}

$12-20-2010$

\title{
Estrellitas girando
}

María Arrillaga

Follow this and additional works at: https://digitalcommons.usf.edu/surcosur

\section{Recommended Citation}

Arrillaga, María. 2010. Estrellitas girando. Revista Surco Sur, Vol. 1: Iss. 2, 6.

DOI: http://dx.doi.org/10.5038/2157-5231.1.2.1

Available at: https://digitalcommons.usf.edu/surcosur/vol1/iss2/2

This POESÍA is brought to you for free and open access by the Open Access Journals at Digital Commons @ University of South Florida. It has been accepted for inclusion in Revista Surco Sur by an authorized editor of Digital Commons@ University of South Florida. For more information, please contact digitalcommons@usf.edu. 


\section{María Arrillaga}

\section{Estrellitas girando \\ A Virginia Woolf}

Susan no tiene gatos

Betty no tiene perros

Jane tiró sus plantas por la ventana

Y no le hizo daño a nadie

Tres:

Susan/Aglaya

Betty/Talía

Jane/Eufrosina

Mis amigas, una magnífica cría de molinetes, como estrellitas girando

Regadas por la ciudad

En colores fuera de serie

Diferentes también sus tamaños, ritmo, velocidad

Mis amigas, las gracias en concierto

Sin miedo, sin vergüenza alguna

Alegres bembetean

Bajo los árboles

En las aceras

En los cafés

Su declaración de independencia

Mientras construyen recién descubiertas realidades De palabra en palabra

Honestas, exigentes, excitadas

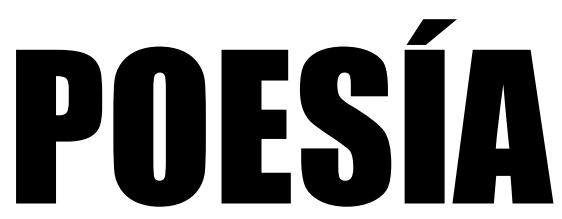

Como es la Babel de sus vidas

Inteligentes

En sus celulares hacen el amor

Como Artemis/Diana y sus amigas

Cuando, para cumplir con su destino,

esperaban a Acteón en aquella orilla del arroyuelo donde la absolutamente fornida defensa de la diosa de la integridad imprimiría la victoria de su tribu mujeril

¡Ay certero salpicón que conjura del pobre venado

el balido que retuerce el corazón!

Mientras

Afrodita continúa

construyendo el acantilado del placer

$Y$ mis amigas

En nuestra fabulosa y desnuda ciudad

Elegantemente vestidas al grito de la moda

Llamativas y cómodas a la vez

Bien peinado el cabello

Luciendo limpias manicuras y pedicuras

Constituyen una espléndida foresta

de estrellitas girando.

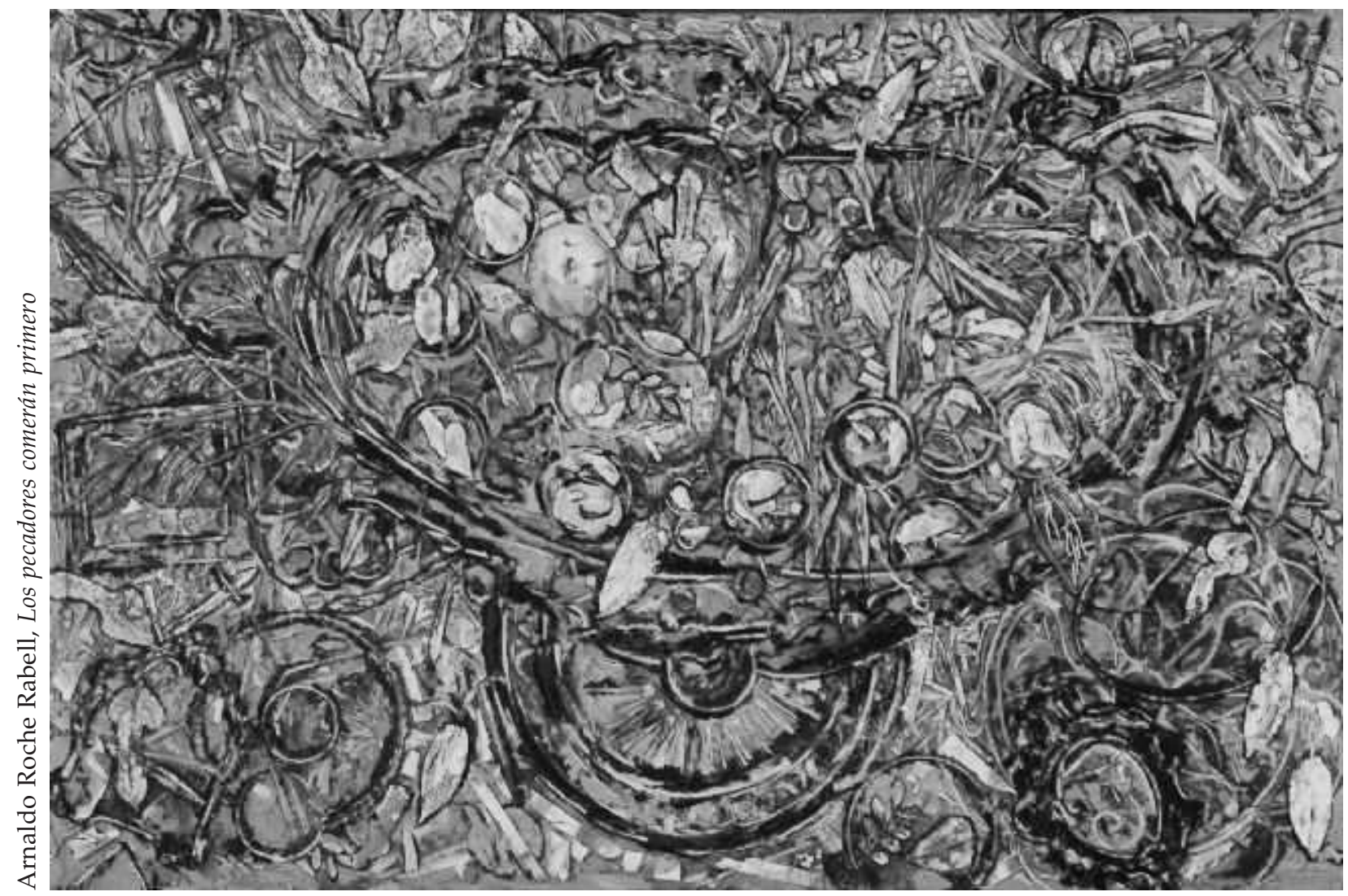

